\title{
Spanish university sued for advertising posts in August
}

[BARCELONA] A Spanish university is being sued by a scientists' association for having advertised 80 posts for professorial appointments last August, a month when many Spanish citizens - and thus potential external applicants - are on holiday.

The Spanish Association for the Advancement of Science and Technology (AACTE) argues that this practice is being deliberately used by the University of La Laguna (ULL) in the Canary Islands to favour the appointment of local candidates. It thus undermines efforts to improve the quality of research in Spanish universities.

In response to the lawsuit, the university says that the practice makes use of administrative resources that would otherwise be underused during the summer. But the university's vice-chancellor has said that it will examine whether things could be done differently in future.

In its lawsuit, the association points out that the strategy of advertising professorial posts in August has been used by the university for several years. In 1997, for example, ULL announced about 60 professorial positions during this period.

The advertisement for applicants for posts in 1998, the last year listed in the lawsuit, was officially issued by the university on 24 July. But it was not published in the daily Official State Bulletin, which publishes all official notices involving Spanish public institutions, until 14 August, reflecting the frequent delay between an institution's decision to advertise and the advertisement's publication. The notice gave applicants 20 working days in which to file their applications with the university.

Economist Ruth Rama, deputy director of the Institute of Economy and Geography in Madrid, and treasurer of the AACTE, argues that advertising university posts during holiday periods is a restrictive practice often intended to favour local candidates.

She says the university may have deliberately chosen the dates of the advertisement to minimize the number of external

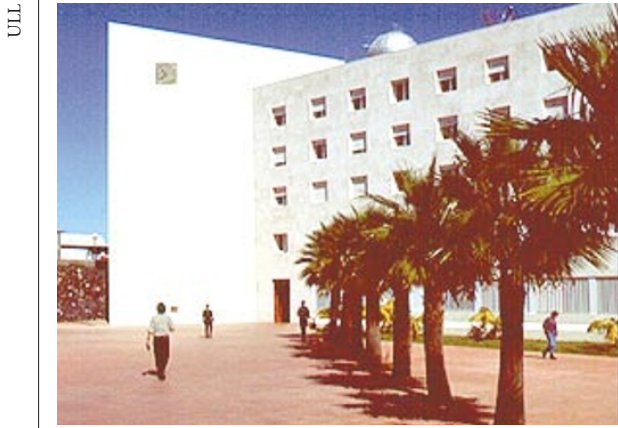

Hiding in the sun? The University of La Laguna.

NATURE | VOL 400 15 JULY 1999 |www.nature.com candidates, and that such practices "violate the constitutional right of equal opportunities for access to public functions that all citizens have".

Rama points out that most public libraries in Spain are closed in August, preventing potential external candidates from reading the daily bulletin. "A virtually total lack of information of the posts is guaranteed," she says.

In a formal response to the AACTE lawsuit to the Canary Islands Superior Court, ULL's legal representative, Miguel Rodríguez Berriel, argues that there is no rule forbidding the universities from advertising posts in August. The university's administrative activities "cannot stop in the holiday period, as that would mean a waste of educative public services".

The AACTE was set up in 1997 by Spanish researchers concerned that Spain was failing to take the steps needed to bring its science up to the level of most advanced countries. One of its main objectives is to monitor the selection procedures for academic positions, and to check whether appointments are made on the basis of academic merit and equal opportunity.

One of its vice-presidents, Luis Rull, professor of physics at the University of Seville, says it is "very appropriate" that ULL has been sued for advertising professorial posts in the summer holiday periods. He says that such tactics undermine "the goal of looking for the best researchers for our universities, and that ULL officials are clearly harming the Canary Islands Autonomous Community".

Rull suggests that university departments in Spain should be ranked according to their research output "so that Spanish citizens are aware of which are the best ones to study at". If not, he says, there will be little pressure to change, as "it may be irrelevant for society that a university tries to appoint mediocre candidates, or even local candidates who have never done research".

The university's vice-chancellor, José Gómez Soliño, denies that the university is trying to hide the posts by advertising them in August. He points out that the university has used the same practice every year, and argues that it is therefore "a problem of bureaucracy" that the advertisements are always published in August.

Gómez Soliño says ULL is not the only Spanish university to advertise professorial posts in August. But he adds that the university intends to study possible ways of avoiding this in future. "We can change things in order that posts are not advertised in August," he says.

XavierBosch

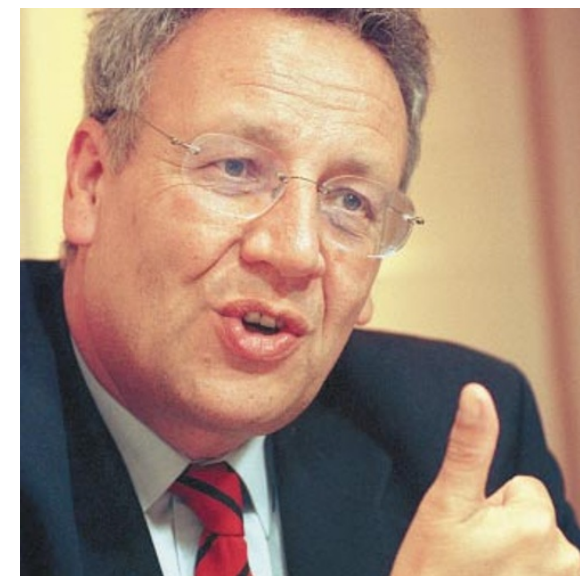

Busquin: solid background in science and politics.

\section{Belgian scientist proposed to head EC research directorate}

[BRUSSELS] A former physicist who took postgraduate degrees in philosophy and environmental studies before turning to politics has been nominated as head of the European Commission's research directorate, DGXII.

Philippe Busquin, leader of Belgium's French-speaking Socialists, is one of a team of proposed commissioners announced last week by Romano Prodi, the president-designate of the European Commission.

All candidates will have to attend individual confirmation hearings with the European Parliament in late August. Centreright MEPs have already voiced criticisms over the left-wing emphasis in Prodi's proposed cabinet.

But Prodi denies any bias. "This is a topquality team in which jobs have been allocated to match the proven abilities and experience of each commissioner," he says.

Busquin, with a solid background in both science and politics, seems well placed to take responsibility for the commission's research programmes, including in particular the fifth Framework programme that began this year. After graduating in physics from the Free University of Brussels (ULB) in 1962, he took a two-year degree in philosophy, followed by postgraduate studies in environmental issues, also at ULB.

He was an assistant lecturer in physics at ULB between 1962 and 1977, while also teaching at Nivelles Teachers' Training College. From 1978 to 1980 he was chairman of the board of directors of the Institut National des Radioéléments in Fleurus.

Elected to the Belgian parliament in 1978, Busquin has been president of the country's Socialist Party since 1992 and held various ministerial positions before being elected a senator in 1995. He was elected to the European Parliament last month. Natasha Loder 